\title{
Parents' Perception of Quality of Life of their Elementary School Children with Hearing
} Impairment Using Hearing Aids

\author{
Marwa Abd-elhamid Atia ${ }^{1}$, Entisar Abo-Elghite Elhossiny Elkazeh', Neamat Mazloum \\ Mohamed $^{3}$ \\ ${ }^{1}$ Nursing specialist Health Insurance Organization- Kafr-Elsheikh Branch \\ ${ }^{2}$ Professor of Community Health Nursing, Faculty of Nursing, Tanta University \\ ${ }^{3}$ Assistant Professor of Community Health Nursing, Faculty of Nursing, Tanta University
}

\begin{abstract}
Background: Hearing impairment is the most common disabilities that have negative impact on the quality of life of affected children and their families. The aim of this study was to: assess parents' perception level of quality of life of their elementary school children with hearing impairment using hearing aids. Subjects and method: Study design: A descriptive study design was utilized in this study. Study settings: This study was conducted in audiology out-patient clinic of the School Health Insurance Hospital at Tanta City. Study subjects: A convenient sampling of 150 of elementary school students who diagnosed with hearing impairment using hearing aids and their parents which constitute 150 were included in the study. Tool of data collection: one tool was used by the researcher to collect the necessary data. Tool I: A structured interview schedule: this tool included five parts: Part (1): Socio-demographic characteristics of the students and their parents. Part (2): History of hearing impairment and using hearing aids. Part (3): History of the academic achievement of the students. Part (4): Children using hearing devices quality of life. Part (5): Pediatric Quality of Life Inventory. Results: about half (47.3\%) of the child's performance after fitting of hearing aids was fair, while less than half $(42.7 \%)$ of them had good, less than two thirds $(61.3 \%)$ of the studied school children' parents had a fair score regarding quality of life and nearly one fifth (20.0\% and $18.7 \%$ respectively) of the studied school children' parents had a good and poor score. Also there was a highly significant positive correlation between levels of pediatric quality of life inventory of the studied school children and the levels of the studied school children parents of their children using hearing device quality of life as $(\mathrm{p}=0.000)$ and $(\mathrm{r}=0.407)$. Conclusion: It can be concluded that, less than two thirds of studied school children parents had a fair score according to their children using hearing devices quality of life. Recommendations: It was recommended that, written instructions about hearing aids in the form of booklets or brochures should be provided to each child with hearing impairment using hearing aids and their parents in order to encourage them in effective adherence to the plan of care.
\end{abstract}

Key words: Parents' Perception, Quality of life, Elementary School, Children, Hearing Impairment, Hearing Aids. 


\section{Introduction}

Hearing is one of the special senses God has bestowed upon human beings. Also hearing is the sensory function that allows us to pick up the sounds, analyze them and assign them meaning ${ }^{(1,2)}$. Furthermore, it is one of the most important functions for development of language and consequently for communication. However, the impact caused by hearing loss has been taken for granted by the society, government and health professionals (3). Hearing impairment is the most frequent sensory deficit in human populations and affects newborns, children, adults and elderly. Therefore, it is an important public health concern with substantial economic and societal costs. Hearing impairment among infants and children retards developmental language and educational progress, but in adults, it causes difficulties in both professional and social life as well as stigmatization $^{(4)}$.

Hearing impairment globally is ranked fourteenth in terms of disability adjusted life years and second in years lived with disability ${ }^{(5)}$. Moreover, it is one of the commonest sensory disabilities worldwide (6). World health organization (WHO) 2014, estimated that over 360 million people had different form of hearing impairment worldwide, and it was found that 328 million were adults while 32 million were children ${ }^{(7)}$. Also hearing impairment was found among $70 \%$ of people in low income countries, and $25 \%$ develop hearing loss during childhood. Additionally infants born in resource-rich countries compared to infants born in resource-poor countries are nearly twice as likely to have hearing loss and about 6 cases/1000 children vs. 2-4 cases/1000 children ${ }^{(6,8)}$.

In Egypt, it was found that the prevalence of hearing impairment comes to $13.8 \%$ in $0-14$ year old children of 1600 surveyed population. The hearing impairment may be unavoidable disability and $75 \%$ of those who suffer from it were living in the developing countries (9). .In South Africa, 2014 about sixteen to seventeen babies every day was born with some degree of hearing impairment (10). In the developed societies, the hearing loss got to be a common issue due to the combined impacts of the noise and hereditary ${ }^{(9)}$.

Hearing impairment results from decreased ability to hear sounds, and can affect the subject to varying degrees which may be mild, moderate, moderate-severe, severe, and profound ${ }^{(2,3)}$. The major causes for hearing impairment among children may be grouped into congenital or acquired ${ }^{(11)}$. Congenital hearing impairment includes chromosome disorder, inborn error of development with usual prelingual 
presentation (12). Acquired hearing impairment may arise from traumatic, inflammatory conditions or metabolic disorders which usually presented as perilingual or postlingual ${ }^{(7)}$. While the major causes of hearing impairment among adults are presbycusis, prolonged exposure to noise, acoustic and physical trauma, and use of ototoxic drugs, antibiotics, and industrial chemicals ${ }^{(4)}$.

There are three main types of hearing impairment :conductive, sensorineural and mixed (13). A conductive hearing impairment occurs in diseases with decreased transmitted sound through external ear canal and middle ear cleft into the inner ear ${ }^{(14)}$. Sensorineural hearing impairment affects sound energy transduction and transmission from inner ear to auditory cortex ${ }^{(6)}$. Mixed hearing impairment is combination of the types of hearing impairments and occurs when more than one type of hearing impairment contributes to the hearing loss ${ }^{(15)}$. Unless such hearing impairment was addressed in a timely manner, it would have a profound impact on the affected children as well as their families and communities, while unaddressed hearing impairment restricts social integration, educational and employment opportunities, delaying of the language acquisition in children, difficulties in communication, hampers emotional well-being, stigmatization, and poses an economic challenge at both the individual and national levels ${ }^{(16,17)}$.

Due to the high prevalence of dysacusis and the harmful consequences that may cause, so, the prevention plays a crucial role for reduction of this problem. In addition to, the prevention of deafness is evidently less expensive than its treatment ${ }^{(3)}$. WHO estimates that $60 \%$ of hearing loss occurring in childhood can be prevented through public health strategies including immunizations, better neonatal care, reduced environmental noise, decreased use of ototoxic medications and effective screening for ear infections ${ }^{(18)}$.

People of all ages with hearing loss can benefit greatly from timely, appropriate and cost-effective interventions, such as speech therapy and hearing devices ${ }^{(19)}$. Early auditory rehabilitation provided by hearing aid devices enables children to substantially improve their verbal language learning and integrate into the hearing world ${ }^{(20)}$. Children with hearing loss may benefit from a range of interventions such as hearing aids, cochlear implants, captioning of text, sign language training and educational and social support (6). Within the past few years, exciting research regarding genetic manipulation, gene therapy and stem cell transplantation as well pharmaceutical agents, suggest that a therapeutic treatment for hearing loss may eventually be possible in the future ${ }^{(4)}$. 
Hearing is important for achieving a good quality of life. WHO has defined quality of life as the individual's perception of their position in life, in the culture context, the value systems in which they live, and in relation to their goals, expectations, standards, and concerns (21). Due to consequences of hearing impairment as difficulties in communication, social isolation, depression and negative feelings can be mentioned that can directly affect the quality of life and the perception that the individual has of their health status, evaluating the quality of life of hearing aid users can be an important indicator of the benefits of amplification, since it allows measuring the implications of a better hearing capacity in activities of daily living, leisure and communication $(2,22)$.

The community health nurse plays an important role in primary health care system in which initial medical consultations are carried out at clinics that are mainly nurse-driven. The nurse gathers information about history of the child, and she should aware of risk factors and monitors the infant's health and development during their visits to the immunization and wellness clinics. Therefore, she was in a good position to integrate information and provide parents with appropriate referral sources. Furthermore, the nurse plays an important role in coordinating first-level detection and intervention. Because of any intervention that may be associated with social stigmatization, or that offends cultural norms, could result in parents missing appointments or cancelling intervention services, therefore nurse is often the best one able to use communication and language to make parents feel relaxed and confident, as well as respected for their choices and culture $^{(10)}$.

\section{The aim of this study was to:}

Assess parents' perception level of quality of life of their elementary school children with hearing impairment using hearing aids.

\section{Research question:}

What is the parents' perception level of quality of life of their elementary school children with hearing impairment using the hearing aids?

\section{Subjects and Method}

\section{Study design:}

A descriptive study design was used to conduct this study.

\section{Study settings:}

This study was conducted in audiology clinic of the School Health Insurance Hospital affiliated to Ministry of Health at Tanta City, Al-Gharbiya Governorate.

\section{Study subjects:}

A convenience sample of 150 of elementary school students that have been 
diagnosed with hearing impairment using hearing aids and their parents which constitute 150 in the previous setting was included in the study.

\section{Study tool:}

A structured interview schedule was developed and used by the researcher in order to obtain the necessary data for this study. It included the following parts:-

\section{Part (1): Socio-demographic}

\section{characteristic of the studied school}

children and their parents ${ }^{(23,24)}$ :

\section{a- Socio-demographic characteristic}

of the studied school children:

This part comprised of six questions included child age, sex, stage and grade level of education, residence and child order among his brothers.

\section{b- Socio-demographic \\ characteristic of the parents:}

This part comprised of nine questions included data about parents' level of education, parents' occupation, income, parental consanguinity, number of children in the family, number of children using hearing aids in the family and previous experience with hearing aids.

\section{Part (2): History of hearing}

impairment and using hearing aids:

a- Past history:

This part comprised of seven questions included data about the causes that lead to hearing impairment, onset and duration of hearing impairment, family history of hearing problems, previous hearing screening or not, age of first diagnoses with hearing impairment.

\section{b- Present history:}

This part comprised of ten questions included data about laterality of hearing impairment and fitting hearing device, degree of hearing impairment, main communication mode, receiving hearing rehabilitation in the first year after fitting the hearing aids, duration of using of hearing aids, duration worn per day, enrollment in speech therapy, regularity of therapy and duration of therapy.

\section{Part (3): History of the academic}

\section{achievement of the studied school}

children $^{(23)}$ as:

This part comprised of ten questions included the performance of the student in the school was (good, fair or poor), communication problems with his/her teachers and classmates after fitting of hearing aids, hard to pay attention in the class after fitting of hearing aids and had trouble kept up with schoolwork and missed school because of communication problems with his/her teachers and classmates after fitting of hearing aids. 
Part (4): Children using hearing device quality of life (CuHDQOL) questionnaire $^{(24)}$ :

This part established by Looi et al., (2016) and was adapted by researcher. The CuHDQOL questionnaire is a new parent-administered hearing-specific QOL questionnaire, developed specifically for children fitted with hearing devices. It included 26 items CuHDQOL questionnaire used a recall period of 1 month and CUHDQOL questionnaire was divided into three subsections as follows: Parental perspectives and expectations, impact on the family and hearing-related QOL of the child.

\section{Scoring system for children using}

hearing device quality of life

(CuHDQOL) questionnaire was as

\section{following:}

A 5-point Likert Scale was used to record children responses $(0=$ strongly disagree, 1 = disagree, 2 = unsure, 3 = agree, and $4=$ strongly agree, with a 'not applicable' option being available), which was transformed to a score from 0 to 130 for statistical analyses. Negatively-voiced questions are reverse scored so that a higher score always indicates a more positive response.

Quality of life score had been classified into three categories as follows:
- Poor quality of life of $0<40 \%$ of the total score.

- Fair quality of life $40 \%-60 \%$ of the total score.

- Good quality of life $>60 \%$ of the total score.

\section{Part (5): Pediatric Quality of Life}

Inventory ${ }^{(25)}$ :

This part established by Petersen et al., (2009) and was adopted by researcher. It was a child report tool. It included 23 items PedQL ${ }^{\mathrm{TM}}$ questionnaire used a recall period of 1 month and PedQL ${ }^{\mathrm{TM}}$ questionnaire was divided into four subsections: health and activities, feelings, getting along with others (social functioning) and school.

\section{The scoring system for Pediatric Quality} of Life Inventory was as follows:

Pediatric Quality of Life Inventory items comprise five response alternatives: $0=$ almost always a problem, 1= often a problem, 2= sometimes a problem, 3= almost never a problem and $4=$ never a problem. These are reversed and transformed to a score from 0 to 100 for statistical analyses.

\section{Pediatric Quality of Life Inventory score} had been classified into three categories as follows:

- Poor quality of life of $0<40 \%$ of the total score.

- Fair quality of life $40 \%-60 \%$ of the 
- total score.

- Good quality of life $>60 \%$ of the total score.

\section{Method}

\section{1- Obtaining approvals:}

- An official permission to conduct the study was obtained from the Dean of Faculty of Nursing to Director of Health Insurance Organization in Tanta City, Al-Gharbiya governorate.

- The director of the outpatient department of Health Insurance was informed about the study objectives to take their permission to collect data from the selected settings.

\section{2- Ethical and legal considerations:}

Ethical and legal considerations that was considered all over the study phases as the following:

- The approval of the ethical committee was obtained.

- An informed consent was obtained from all study subjects after providing appropriate explanation about the purpose and the benefits of the study.

- Nature of the study were not cause any harm or pain for the entire sample.

- Privacy and confidentiality were put into consideration regarding the data collected.

- The rights to abstain or terminate participation at any time were respected.

\section{3- Developing the tools:}

- The study tools were developed and translated into Arabic language by the researcher based on literature review, modified to suit the level of understanding of all subjects and were tested for translation by experts in English language.

- The study tools were tested for its content validity by a jury of five professors in Community Health Nursing at Faculty of Nursing in Tanta University and Public Health Medicine before conducting the study.

\section{4- The pilot study:}

- A pilot study was carried out by the researcher on 15 school children and their parents from audiology clinic of school health insurance for testing the tool for its clarity, applicability and identifies obstacles that may be encountered during data collection. Accordingly, the necessary modifications were done. Those school children and their parents were excluded from the study sample.

- To assess the reliability, the study tool was given to fifteen school children and their parents (pilot study). By using Cronbach's alpha test, it was found to be (0.821) which indicate highly reliable tool. 


\section{5- The actual study:}

- School children and their parents were interviewed at audiology clinic of school Health Insurance hospital by the researcher using the previous tools to collect the necessary data.

- Collection of data was continued about six months, starting at April 2019 and ending in August 2019. The time needed for each interview to complete the data collection sheet ranged from 30-40 minutes.

\section{6- Statistical analysis:}

- The statistical data were organized, tabulated and statistically analyzed using statistical package for the social studies (SPSS) version 25. For quantitative data, the range, mean and standard deviation were calculated. For qualitative data which describe a categorical set of data by frequency, percentage or proportion of each category, comparison was done using Chi-square test $\left(\chi^{2}\right)$. Correlation between variables was evaluated using Pearson and Spearman's correlation coefficient (r). The level of significance was adopted at $\mathrm{P}<0.05$ for interpretation results of tests of significance. Also, a highly significance was adopted at $\mathrm{P}<0.01$ for interpretation of results of tests of significance.

\section{Results}

Table (I): Distribution of the studied school children according to their history of the academic educational achievement. This table shows that about half $(47.3 \%)$ of the child's performance after fitting of hearing aids was fair, while less than half (42.7\%) of them had a good, and only few $(10.0 \%)$ of them had a poor performance. As regards attention affection of the child in the classroom after fitting of hearing aids, the majority $(82.0 \%)$ of them weren't affected. Concerning the child facing problem to communicate with classmates and teachers at school after fitting of hearing aids, about more than three-quarters $(78.0 \%)$ of them weren't faced any problem. In relation to child absent from school due to inability to communicate with classmates and teachers, the majority $(83.3 \%)$ of them weren't absent from school.

Table (2): Distribution of the studied school children' parents according to their perspectives and expectations. This table shows that about $35.3 \%, 43.3 \%$ and $42.7 \%$ of the studied school children parents were reported that sometimes their child easily made friends with other children, their child's spoken language was similar to typically developing children their own age and they believed 
that their child has greater educational opportunities and achievements with their hearing device respectively, while about less than one- half ( $48.7 \%$ ) of them reported that their child often needs more of my daily attention than other. Also this table reveals that about $46.0 \%, 56.7 \%$, $46.7 \%$ and $42.7 \%$ of them was believed that sometimes as an adult their child is able to find employment and support themselves, their child leads a happy life, their child feels safe in the world and their child feels confident in the world respectively.

Table (3): Distribution of the studied school children' parents according to the using of hearing aids impact on the family. This table reveals that more than one- third $(34.0 \%)$ of the studied school children' parents reported that rarely they always worry about whether the hearing device is working correctly, while about $28.7 \%$, $52.0 \%, 48.7 \%$ and $41.3 \%$ of them reported that often their financial situation is stressed by the ongoing costs to maintain the hearing device, they devote more time to my child than other members of my family, the hearing device has improved communication between their immediate family members and their child's hearing needs place additional stress on their immediate family respectively. It also shows that about $48.0 \%, 56.0 \%$ and $54.0 \%$ of them reported that sometimes their immediate family's activities are limited by their child's hearing needs, the future educational placement and achievement for their child is a concern for their immediate family and they have had to change their working patterns since their child received the hearing device respectively.

Table (4): Distribution of the studied school children' parents according to the hearing-related quality of life (QoL) of their children. This table shows that $38.0 \%, 44.7 \%, 45.3 \%, 45.3 \%, 42.0 \%$ and $48.7 \%$ of them reported that sometimes their child is able to communicate their needs using spoken language, their child is confident in social situations with typically developing children their his age, their child's speech is clear and can be understood by people who have not met them before, their child overhears conversation that is not directed at them and asks questions about what was said, their child keeps up with their peers for daily learning activities at preschool/kindergarten/school and their child is often afraid of new situations respectively. Also this table reveals that about $43.3 \%, 46.0 \%, 46.7 \%$ and $40.0 \%$ of them reported that rarely their child initiates conversations with other children and adults, their child is often ill and asks to stay home from school, their child enjoys music and their child tires more 
easily than other typically developing children their own age respectively.

Table (5): Distribution of the studied school children' parents according to their domains levels of their children using hearing devices (QOL). This table illustrates that less than half $(48.7 \%$ and $30.7 \%$ ) of parent's perspectives and expectations of the studied school children' parents had a fair and a good score respectively and only one fifth (20.7\%) had a poor score with a mean $24.68 \pm 4.969$. Concerning the studied school children' parents according to their children using hearing devices impact on the family also about less than half $(46.7 \%$ and $36.0 \%)$ had a fair and a poor score respectively, while only the minority $(17.3 \%)$ had a good score with a mean 21.87 \pm 4.634 . Regarding the studied school children' parents according to their children using hearing device hearing-related quality of life of the child about less than two-thirds $(64.7 \%)$ had a fair score and only $24 \%$ and $11.3 \%$ had a good and a poor score respectively with a mean $31.17 \pm 5.149$.

Table (6): Distribution of total score of the studied school children' parents according to their children using hearing device quality of life. This table shows that less than two-thirds $(61.3 \%)$ of the studied school children' parents had a fair score related to their children using hearing device quality of life and nearly one-fifth
(20.0\% and $18.7 \%)$ of them had a good and a poor score according to their children using hearing device quality of life respectively with a mean $77.71 \pm 12.441$.

Table (7): Distribution of the studied school children according to their health and activities problems. As regards to the child health and activities problems, it was found that less than three-quarters $(73.3 \%)$ of them reported that never had problem to take a bath or shower by themselves, while less than one- half $(49.3 \%, 47.3 \%$ and $48.0 \%$ ) of them reported that never had these problems (hard to walk more than one block, hard to do sports activities or exercises and hard to left something heavy) respectively.

While nearly three -quarters $(73.3 \%)$ of them mentioned that it is hard for them to take a bath or shower by themselves. Also more than half $(56.7 \%$ and $54.0 \%)$ of their children reported that their children never had these problems (hard to do chores around the house and hard for them to run) respectively. As regards to the other child activities problems as they hurt or ache, it was reported that sometimes less than two -thirds $(60.0 \%)$ of them had this problem. While less than one- half $(42.7 \%)$ of them reported that almost never have low energy.

Table (8): Distribution of the studied school children according to their feelings 
problems. This table reveals that about two -thirds $(66.7 \%)$ of them reported that sometimes they feel sad or blue and more than half $(62.0 \%, 56.7 \%$ and $57.3 \%)$ of them reported that sometimes they feel afraid or scared, feel angry and worry about what will happen to them respectively. While half $(50.7 \%)$ of them reported that they never have trouble sleeping.

Table (9): Distribution of the studied school children according to their problems of getting along with others. This table illustrates that less than half $(45.3 \%$, $44.0 \%, 41.3 \%$ and $41.3 \%$ ) of them reported that sometimes other children tease them, it is hard to keep up when they play with other children, have trouble getting along with other children and other children do not want to be their friends respectively. While less than one -half $(42.0 \%)$ of them reported that almost never they can't do things that other children with their age can do.

Table (10): Distribution of the studied school children regarding to their problems with school. This table represents that about half $(48.0 \%)$ of them reported that sometimes hard to pay attention in class, while more than one -third $(44.0 \%, 46.7 \%$ and $38.7 \%$ ) of them reported that they almost never have trouble keeping up with their school work, they often miss school because of not feeling well and they often miss school to go to the doctor or hospital respectively, while more than two- fifths $(42.7 \%)$ of them reported that they never forget things.

Table (11): Distribution of the studied school children according to their domains levels of pediatric quality of life inventory. This table illustrates that the majority $(82.7 \%)$ of the studied school children had a good score of pediatric quality of life inventory health and activities, while the minority $(14.7 \%$ and $2.7 \%$ ) of them had a fair and a poor score of pediatric quality of life inventory health and activities respectively with a mean $32.83 \pm 5.557$.

Concerning the studied school children feelings more than half $(60.0 \%)$ of them had a fair score, while about $34.0 \%$ and $6.0 \%$ had a good and a poor score respectively with a mean $16.75 \pm 2.999$. As regards to the studied school children problems of getting along with others, about less than one- half $(48.0 \%)$ of them had a fair score, while about $42.7 \%$ and $9.3 \%$ of them had a good and a poor score respectively with a mean $16.89 \pm 3.639$. Regarding the studied school children problems with school the majority (75.3\%) of them had a good score, while about $18.0 \%$ and $6.7 \%$ of them had a fair and a poor score respectively with a mean $18.87 \pm 3.654$. 
Table (12): Distribution of the studied school children according to their levels of pediatric quality of life inventory. This table shows that more than three -quarters (77.3\%) of studied school children had a good score regarding to the levels of pediatric quality of life inventory, while about one- fifth $(20.0 \%)$ of them had a fair score and the minority $(2.7 \%)$ of them had a poor score as regards to the levels of pediatric quality of life inventory with a mean of $85.33 \pm 11.583$.

Table (13): Correlation between levels of pediatric quality of life inventory of children and the levels of the parents according to their children using hearing device quality of life. This table shows that there was a highly significant positive correlation between levels of pediatric quality of life inventory of the studied school children and levels of the studied school children' parents according to their children using hearing device quality of life as $(\mathrm{p}=0.000)$ and $(\mathrm{r}=0.407)$. 
Table (I): Distribution of the studied school children according to their history of the academic educational achievement

\begin{tabular}{|c|c|c|}
\hline \multirow[t]{2}{*}{ History of the academic educational achievement } & \multicolumn{2}{|c|}{$\begin{array}{c}\text { The studied } \\
\text { school children } \\
(n=150)\end{array}$} \\
\hline & No & $\%$ \\
\hline $\begin{array}{l}\text { 1.Child's performance in school after fitting of hearing aids } \\
-\quad \text { Good } \\
-\quad \text { Fair } \\
-\quad \text { Poor }\end{array}$ & $\begin{array}{l}64 \\
71 \\
15\end{array}$ & $\begin{array}{l}42.7 \\
47.3 \\
10.0\end{array}$ \\
\hline $\begin{array}{l}\text { 2.Fitting of hearing aids affect attention of the child in the } \\
\text { classroom } \\
\text { - Affect attention } \\
\text { - Not affect attention }\end{array}$ & $\begin{array}{r}27 \\
123\end{array}$ & $\begin{array}{l}18.0 \\
82.0\end{array}$ \\
\hline $\begin{array}{l}\text { 3.Child faces problem to communicate with classmates and } \\
\text { teachers at school } \\
\text { - Faces problem } \\
\text { - Not face problem }\end{array}$ & $\begin{array}{c}33 \\
117\end{array}$ & $\begin{array}{l}22.0 \\
78.0\end{array}$ \\
\hline $\begin{array}{l}\text { 4.Child absent from school due to inability to communicate with } \\
\text { classmates and teachers } \\
\text { - } \quad \text { Absent } \\
\text { - Not absent }\end{array}$ & $\begin{array}{c}25 \\
125\end{array}$ & $\begin{array}{l}16.7 \\
83.3\end{array}$ \\
\hline
\end{tabular}


Table (2): Distribution of the studied school children' parents according to their perspectives and expectations

\begin{tabular}{|c|c|c|c|c|c|c|c|c|c|c|}
\hline \multirow{3}{*}{$\begin{array}{l}\text { Parents perspectives } \\
\text { and expectations }\end{array}$} & \multicolumn{10}{|c|}{$\begin{array}{l}\text { The studied parents } \\
\text { (n=150) }\end{array}$} \\
\hline & \multicolumn{2}{|c|}{ Never } & \multicolumn{2}{|c|}{ Rarely } & \multicolumn{2}{|c|}{ Sometimes } & \multicolumn{2}{|c|}{ Often } & \multicolumn{2}{|c|}{ Always } \\
\hline & No & $\%$ & $\overline{\text { No }}$ & $\%$ & $\overline{\text { No }}$ & $\%$ & No & $\%$ & No & $\%$ \\
\hline $\begin{array}{l}\text { 1. Child easily makes friends } \\
\text { with other children. }\end{array}$ & 2 & 1.3 & 29 & 19.3 & 53 & 35.3 & 47 & 31.3 & 19 & 12.7 \\
\hline $\begin{array}{l}\text { 2. Child's spoken language is } \\
\text { similar to typically } \\
\text { developing children their } \\
\text { own age. }\end{array}$ & 2 & 1.3 & 29 & 19.3 & 65 & 43.3 & 41 & 27.3 & 13 & 8.7 \\
\hline $\begin{array}{l}\text { 3. Believe child will have } \\
\text { greater } \\
\text { opportunities } \\
\text { educational } \\
\text { achievements with their } \\
\text { hearing device. }\end{array}$ & 2 & 1.3 & 27 & 18.0 & 64 & 42.7 & 53 & 35.3 & 4 & 2.7 \\
\hline $\begin{array}{l}\text { 4. Child needs more of daily } \\
\text { attention than other. }\end{array}$ & 2 & 1.3 & 12 & 8.0 & 46 & 30.7 & 73 & 48.7 & 17 & 11.3 \\
\hline $\begin{array}{l}\text { 5. Believe that as an adult the } \\
\text { child will be able to find } \\
\text { employment and support } \\
\text { themselves. }\end{array}$ & 0 & 0.0 & 30 & 20.0 & 69 & 46.0 & 51 & 34.0 & 0 & 0.0 \\
\hline $\begin{array}{l}\text { 6. Believe that child will lead } \\
\text { a happy life. }\end{array}$ & 2 & 1.3 & 12 & 8.0 & 85 & 56.7 & 46 & 30.7 & 5 & 3.3 \\
\hline $\begin{array}{l}\text { 7. I believe that my child will } \\
\text { feel safe in the world. }\end{array}$ & 4 & 2.7 & 33 & 22.0 & 70 & 46.7 & 36 & 24.0 & 7 & 4.7 \\
\hline $\begin{array}{l}\text { 8. Believe that child will feel } \\
\text { confident in the world. }\end{array}$ & 4 & 2.7 & 37 & 24.7 & 64 & 42.7 & 38 & 25.3 & 7 & 4.7 \\
\hline
\end{tabular}


Table (3): Distribution of the studied school children' parents according to the using of hearing aids impact on the family

\begin{tabular}{|c|c|c|c|c|c|c|c|c|c|c|}
\hline \multirow{3}{*}{ Impact on the family } & \multicolumn{10}{|c|}{$\begin{array}{l}\text { The studied parents } \\
\qquad(\mathrm{n}=150)\end{array}$} \\
\hline & \multicolumn{2}{|c|}{ Never } & \multicolumn{2}{|c|}{ Rarely } & \multicolumn{2}{|c|}{ Sometimes } & \multicolumn{2}{|c|}{ Often } & \multicolumn{2}{|c|}{ Always } \\
\hline & No & $\%$ & No & $\%$ & No & $\%$ & No & $\%$ & No & $\%$ \\
\hline $\begin{array}{llr}\text { 1. Always worry } & \text { about } \\
\text { whether the hearing } \\
\text { device is } \\
\text { correctly. }\end{array}$ & 36 & 24.0 & 51 & 34.0 & 44 & 29.3 & 17 & 11.3 & 2 & 1.3 \\
\hline $\begin{array}{l}\text { 2. Financial situation is } \\
\text { stressed by the ongoing } \\
\text { costs to maintain the } \\
\text { hearing device. }\end{array}$ & 8 & 5.3 & 29 & 19.3 & 38 & 25.3 & 43 & 28.7 & 32 & 21.3 \\
\hline $\begin{array}{l}\text { 3. Devote more time to the } \\
\text { child than other members } \\
\text { of my family. }\end{array}$ & 0 & 0.0 & 11 & 7.3 & 48 & 32.0 & 78 & 52.0 & 13 & 8.7 \\
\hline $\begin{array}{l}\text { 4. Immediate family's } \\
\text { activities are limited by } \\
\text { child's hearing needs. }\end{array}$ & 5 & 3.3 & 19 & 12.7 & 72 & 48.0 & 52 & 34.7 & 2 & 1.3 \\
\hline $\begin{array}{l}\text { 5. The hearing device has } \\
\text { improved communication } \\
\text { between immediate } \\
\text { family members. }\end{array}$ & 4 & 2.7 & 2 & 1.3 & 55 & 36.7 & 73 & 48.7 & 16 & 10.7 \\
\hline $\begin{array}{l}\text { 6. The future educational } \\
\text { placement and } \\
\text { achievement for the child } \\
\text { is a concern for } \\
\text { immediate family. }\end{array}$ & 4 & 2.7 & 10 & 6.7 & 84 & 56.0 & 38 & 25.3 & 14 & 9.3 \\
\hline $\begin{array}{l}\text { 7. Had to change our } \\
\text { working patterns since } \\
\text { our child received their } \\
\text { hearing device. }\end{array}$ & 5 & 3.3 & 20 & 13.3 & 81 & 54.0 & 36 & 24.0 & 8 & 5.3 \\
\hline $\begin{array}{l}\text { 8. Child's hearing needs } \\
\text { place additional stress on } \\
\text { immediate family. }\end{array}$ & 2 & 1.3 & 16 & 10.7 & 61 & 40.7 & 62 & 41.3 & 9 & 6.0 \\
\hline
\end{tabular}


Table (4): Distribution of the studied school children' parents according to the hearingrelated quality of life (QOL) of their children

\begin{tabular}{|c|c|c|c|c|c|c|c|c|c|c|}
\hline \multirow{3}{*}{$\begin{array}{c}\text { Hearing-related QOL of the } \\
\text { child }\end{array}$} & \multicolumn{10}{|c|}{$\begin{array}{l}\text { The studied parents } \\
\qquad(\mathrm{n}=\mathbf{1 5 0})\end{array}$} \\
\hline & \multicolumn{2}{|c|}{ Never } & \multicolumn{2}{|c|}{ Rarely } & \multicolumn{2}{|c|}{ Sometimes } & \multicolumn{2}{|c|}{ Often } & \multicolumn{2}{|c|}{ Always } \\
\hline & \begin{tabular}{|l|} 
No \\
\end{tabular} & $\%$ & No & $\%$ & No & $\%$ & No & $\%$ & No & $\%$ \\
\hline $\begin{array}{l}\text { 1. Child is able to } \\
\text { communicate their needs } \\
\text { using spoken language }\end{array}$ & 2 & 1.3 & 17 & 11.3 & 57 & 38.0 & 43 & 28.7 & 31 & 20.7 \\
\hline $\begin{array}{l}\text { 2. Child is confident in } \\
\text { social situations with } \\
\text { typically developing } \\
\text { children their own age. }\end{array}$ & 2 & 1.3 & 40 & 26.7 & 67 & 44.7 & 34 & 22.7 & 7 & 4.7 \\
\hline $\begin{array}{l}\text { 3. Child initiates } \\
\text { conversations with other } \\
\text { children and adults. }\end{array}$ & 2 & 1.3 & 65 & 43.3 & 55 & 36.7 & 24 & 16.0 & 4 & 2.7 \\
\hline $\begin{array}{l}\text { 4. Child's speech is clear } \\
\text { and can be understood by } \\
\text { people who have not met } \\
\text { them before. }\end{array}$ & 4 & 2.7 & 30 & 20.0 & 68 & 45.3 & 38 & 25.3 & 10 & 6.7 \\
\hline $\begin{array}{l}\text { 5. Child is often ill and asks } \\
\text { to stay home from school }\end{array}$ & 19 & 12.7 & 69 & 46.0 & 45 & 30.0 & 14 & 9.3 & 3 & 2.0 \\
\hline $\begin{array}{l}\text { 6. Child overhears } \\
\text { conversation that is not } \\
\text { directed at them and asks } \\
\text { questions about what was } \\
\text { said. }\end{array}$ & 5 & 3.3 & 25 & 16.7 & 68 & 45.3 & 40 & 26.7 & 12 & 8.0 \\
\hline $\begin{array}{l}\text { 7. Child keeps up with their } \\
\text { peers for daily learning } \\
\text { activities at } \\
\text { preschool/kindergarten/sc } \\
\text { hool. }\end{array}$ & 5 & 3.3 & 31 & 20.7 & 63 & 42.0 & 42 & 28.0 & 9 & 6.0 \\
\hline 8. Child enjoys music. & 12 & 8.0 & 70 & 46.7 & 36 & 24.0 & 26 & 17.3 & 6 & 4.0 \\
\hline $\begin{array}{l}\text { 9. Child tires more easily } \\
\text { than other typically } \\
\text { developing children their } \\
\text { own age. }\end{array}$ & 16 & 10.7 & 60 & 40.0 & 48 & 32.0 & 22 & 14.7 & 4 & 2.7 \\
\hline $\begin{array}{l}\text { 10. Child is often afraid of } \\
\text { new situations. }\end{array}$ & 12 & 8.0 & 32 & 21.3 & 73 & 48.7 & 31 & 20.7 & 2 & 1.3 \\
\hline
\end{tabular}


Table (5): Distribution of the studied school children' parents according to their domains levels of their children using hearing devices (QOL)

\begin{tabular}{|c|c|c|}
\hline \multirow[t]{2}{*}{ Domains of the hearing related QOL } & \multicolumn{2}{|c|}{$\begin{array}{l}\text { The studied school children' parents } \\
(\mathbf{n = 1 5 0 )}\end{array}$} \\
\hline & No & $\%$ \\
\hline $\begin{array}{l}\text { 1-Parent perspectives \& expectations } \\
-\quad \text { Poor } \\
-\quad \text { Fair } \\
-\quad \text { Good }\end{array}$ & $\begin{array}{l}31 \\
73 \\
46\end{array}$ & $\begin{array}{l}20.7 \\
48.7 \\
30.7\end{array}$ \\
\hline $\begin{array}{c}\text { Range } \\
\text { Mean } \pm \text { SD }\end{array}$ & \multicolumn{2}{|c|}{$\begin{array}{c}(16-37) \\
24.68 \pm 4.969\end{array}$} \\
\hline $\begin{array}{l}\text { 2-Impact on family } \\
-\quad \text { Poor } \\
-\quad \text { Fair } \\
-\quad \text { Good }\end{array}$ & $\begin{array}{l}54 \\
70 \\
26\end{array}$ & $\begin{array}{l}36.0 \\
46.7 \\
17.3\end{array}$ \\
\hline $\begin{array}{c}\text { Range } \\
\text { Mean } \pm \text { SD }\end{array}$ & \multicolumn{2}{|c|}{$\begin{array}{c}(13-33) \\
21.87 \pm 4.634 \\
\end{array}$} \\
\hline $\begin{array}{l}\text { 3-Hearing-related quality of life of the child } \\
-\quad \text { Poor } \\
-\quad \text { Fair } \\
-\quad \text { Good }\end{array}$ & $\begin{array}{l}17 \\
97 \\
36\end{array}$ & $\begin{array}{l}11.3 \\
64.7 \\
24.0\end{array}$ \\
\hline $\begin{array}{c}\text { Range } \\
\text { Mean } \pm \text { SD }\end{array}$ & \multicolumn{2}{|c|}{$\begin{array}{c}(21-48) \\
31.17 \pm 5.149\end{array}$} \\
\hline
\end{tabular}

Table (6): Distribution of total score of the studied school children' parents according to their children using hearing device quality of life

\begin{tabular}{|c|c|c|}
\hline \multirow[t]{2}{*}{$\begin{array}{l}\text { Total score Levels of the studied school children' parents } \\
\text { according to their (CUHDQOL) }\end{array}$} & \multicolumn{2}{|c|}{$\begin{array}{l}\text { The studied school } \\
\text { children' parents } \\
(\mathbf{n = 1 5 0 )}\end{array}$} \\
\hline & No & $\%$ \\
\hline - Poor & 28 & 18.7 \\
\hline - Fair & 92 & 61.3 \\
\hline - Good & 30 & 20.0 \\
\hline $\begin{array}{c}\text { Range } \\
\text { Mean } \pm \text { SD }\end{array}$ & $(54-110)$ & 441 \\
\hline
\end{tabular}


Table (7): Distribution of the studied school children according to their health and activities problems

\begin{tabular}{|c|c|c|c|c|c|c|c|c|c|c|}
\hline \multirow{3}{*}{$\begin{array}{c}\text { Child health and activities } \\
\text { problems }\end{array}$} & \multicolumn{10}{|c|}{$\begin{array}{l}\text { The studied school children } \\
\text { (n=150) }\end{array}$} \\
\hline & \multicolumn{2}{|c|}{$\begin{array}{l}\text { Almost } \\
\text { always } \\
\end{array}$} & \multicolumn{2}{|c|}{ Often } & \multicolumn{2}{|c|}{ Sometimes } & \multicolumn{2}{|c|}{$\begin{array}{c}\text { Almost } \\
\text { never }\end{array}$} & \multicolumn{2}{|c|}{ Never } \\
\hline & No & $\%$ & No & $\%$ & $\mathbf{0}$ & $\%$ & No & $\%$ & No & $\%$ \\
\hline $\begin{array}{l}\text { 1. It is hard to walk more } \\
\text { than one block. }\end{array}$ & 0 & 0.0 & 2 & 1.3 & 31 & 20.7 & 43 & 28.7 & 74 & 49.3 \\
\hline 2. It is hard to run. & 0 & 0 & 4 & 2.7 & 27 & .0 & 38 & 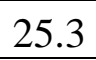 & 81 & 54.0 \\
\hline $\begin{array}{l}\text { 3. It is hard to do sports } \\
\text { activities or exercises. }\end{array}$ & 0 & 0.0 & 6 & 4.0 & 25 & 16.7 & 48 & 32.0 & 71 & 47.3 \\
\hline $\begin{array}{l}\text { 4. It is hard to left something } \\
\text { heavy }\end{array}$ & 2 & 1.3 & 9 & 6.0 & 28 & 18.7 & 39 & 26.0 & 72 & 48.0 \\
\hline $\begin{array}{l}\text { 5. It is hard to take a bath or } \\
\text { shower by myself. }\end{array}$ & 3 & 2.0 & 4 & 2.7 & 15 & 10.0 & 18 & 12.0 & 110 & 73.3 \\
\hline $\begin{array}{l}\text { 6. It is hard to do chores } \\
\text { around the house. }\end{array}$ & 2 & 1.3 & 6 & 4.0 & 16 & 10.7 & 41 & 27.3 & 85 & 56.7 \\
\hline 7. Hurt or ache. & 2 & 1.3 & 11 & 1.3 & 90 & 60.0 & 29 & 19.3 & 18 & 12.0 \\
\hline 8. Have low energy. & 0 & 0.0 & 13 & 8.7 & 45 & 30.0 & 64 & 42.7 & 28 & 18.7 \\
\hline
\end{tabular}

Table (8): Distribution of the studied school children according to their feelings problems

\begin{tabular}{|c|c|c|c|c|c|c|c|c|c|c|}
\hline \multirow{3}{*}{ Child feelings } & \multicolumn{10}{|c|}{$\begin{array}{l}\text { The studied school children } \\
\text { (n=150) }\end{array}$} \\
\hline & \multicolumn{2}{|c|}{$\begin{array}{l}\text { Almost } \\
\text { always }\end{array}$} & \multicolumn{2}{|c|}{ Often } & \multicolumn{2}{|c|}{ Sometimes } & \multicolumn{2}{|c|}{ Almost never } & \multicolumn{2}{|c|}{ Never } \\
\hline & No & $\%$ & No & $\%$ & No & $\%$ & No & $\%$ & No & $\%$ \\
\hline $\begin{array}{l}\text { 1. Feeling } \\
\text { afraid or } \\
\text { scared. }\end{array}$ & 2 & 1.3 & 9 & 6.0 & 93 & 62.0 & 38 & 25.3 & 8 & 5.3 \\
\hline $\begin{array}{l}\text { 2. Feeling sad } \\
\text { or blue. }\end{array}$ & 2 & 1.3 & 19 & 12.7 & 100 & 66.7 & 19 & 12.7 & 10 & 6.7 \\
\hline $\begin{array}{l}\text { 3. Feeling } \\
\text { angry. }\end{array}$ & 0 & 0.0 & 44 & 29.3 & 85 & 56.7 & 11 & 7.3 & 10 & 6.7 \\
\hline $\begin{array}{l}\text { 4. Having } \\
\text { trouble } \\
\text { sleeping. }\end{array}$ & 4 & 2.7 & 5 & 3.3 & 28 & 18.7 & 37 & 24.7 & 76 & 50.7 \\
\hline $\begin{array}{l}\text { 5. Worrying } \\
\text { about what } \\
\text { will happen. }\end{array}$ & 2 & 1.3 & 17 & 11.3 & 86 & 57.3 & 27 & 18.0 & 18 & 12.0 \\
\hline
\end{tabular}


Table (9): Distribution of the studied school children according to their problems of getting along with others.

\begin{tabular}{|c|c|c|c|c|c|c|c|c|c|c|}
\hline \multirow{3}{*}{$\begin{array}{c}\text { Child problems of getting } \\
\text { along } \\
\text { with others }\end{array}$} & \multicolumn{10}{|c|}{$\begin{array}{l}\text { The studied school children } \\
\text { (n=150) }\end{array}$} \\
\hline & \multicolumn{2}{|c|}{$\begin{array}{l}\text { Almost } \\
\text { always }\end{array}$} & \multicolumn{2}{|c|}{ Often } & \multicolumn{2}{|c|}{ Sometimes } & \multicolumn{2}{|c|}{$\begin{array}{c}\text { Almost } \\
\text { never }\end{array}$} & \multicolumn{2}{|c|}{ Never } \\
\hline & No & $\%$ & No & $\%$ & No & $\%$ & No & $\%$ & No & $\%$ \\
\hline $\begin{array}{l}\text { 1. Having trouble for getting } \\
\text { along with other children. }\end{array}$ & 2 & 1.3 & 6 & 4.0 & 62 & 41.3 & 60 & 40.0 & 20 & 13.3 \\
\hline $\begin{array}{l}\text { 2. Other children do not want } \\
\text { to be friend. }\end{array}$ & 2 & 1.3 & 16 & 10.7 & 62 & 41.3 & 50 & 33.3 & 20 & 13.3 \\
\hline 3. Other children tease me. & 2 & 1.3 & 59 & 39.3 & 68 & 45.3 & 14 & 9.3 & 7 & 4.7 \\
\hline $\begin{array}{l}\text { 4. Cannot do things that other } \\
\text { children with age can do. }\end{array}$ & 4 & 2.7 & 12 & 8.0 & 52 & 34.7 & 63 & 42.0 & 19 & 12.7 \\
\hline $\begin{array}{l}\text { 5. It is hard to keep up when } \\
\text { play with other children. }\end{array}$ & 2 & 1.3 & 10 & 6.7 & 66 & 44.0 & 53 & 35.3 & 19 & 12.7 \\
\hline
\end{tabular}

Table (10): Distribution of the studied school children regarding to their problems with school

\begin{tabular}{|c|c|c|c|c|c|c|c|c|c|c|}
\hline \multirow{3}{*}{$\begin{array}{l}\text { Problems of the child } \\
\text { with school }\end{array}$} & \multicolumn{10}{|c|}{$\begin{array}{l}\text { The studied school children } \\
\qquad(\mathrm{n}=150)\end{array}$} \\
\hline & \multicolumn{2}{|c|}{$\begin{array}{l}\text { Almost } \\
\text { always }\end{array}$} & \multicolumn{2}{|c|}{ Often } & \multicolumn{2}{|c|}{ Sometimes } & \multicolumn{2}{|c|}{$\begin{array}{c}\text { Almost } \\
\text { never }\end{array}$} & \multicolumn{2}{|c|}{ Never } \\
\hline & No & $\%$ & No & $\%$ & No & $\%$ & No & $\%$ & No & $\%$ \\
\hline $\begin{array}{l}\text { 1. It is hard to pay } \\
\text { attention in class. }\end{array}$ & 2 & 1.3 & 8 & 5.3 & 72 & 48.0 & 45 & 30.0 & 23 & 15.3 \\
\hline 2. Forgetting things. & 2 & 1.3 & 8 & 5.3 & 38 & 25.3 & 38 & 25.3 & 64 & 42.7 \\
\hline $\begin{array}{l}\text { 3. Having trouble } \\
\text { keeping up with } \\
\text { school work. }\end{array}$ & 2 & 1.3 & 8 & 5.3 & 53 & 35.3 & 66 & 44.0 & 21 & 14.0 \\
\hline $\begin{array}{l}\text { 4. Missing school } \\
\text { because of not } \\
\text { feeling well. }\end{array}$ & 4 & 2.7 & 10 & 6.7 & 35 & 23.3 & 70 & 46.7 & 31 & 20.7 \\
\hline $\begin{array}{l}\text { 5. Missing school to go } \\
\text { to the doctor or } \\
\text { hospital. }\end{array}$ & 4 & 2.7 & 10 & 6.7 & 43 & 28.7 & 58 & 38.7 & 35 & 23.3 \\
\hline
\end{tabular}


Table (11): Distribution of the studied school children according to their domains levels of pediatric quality of life inventory

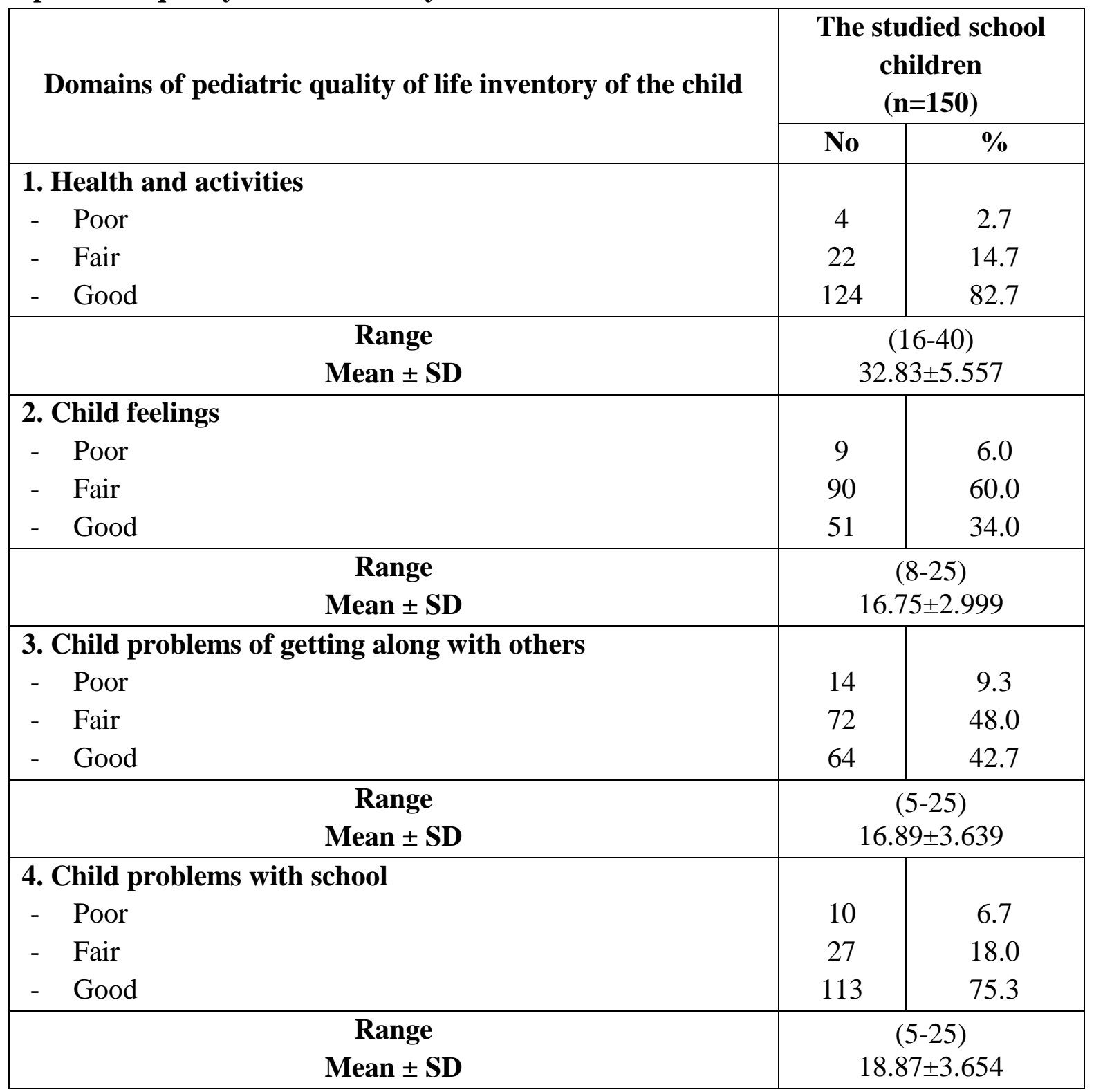

Table (12): Distribution of the studied school children according to their levels of pediatric quality of life inventory

\begin{tabular}{|l|c|c|}
\hline \multirow{2}{*}{ Levels of pediatric quality of life inventory of the child } & \multicolumn{2}{|c|}{$\begin{array}{c}\text { The studied school children } \\
(\mathbf{n = 1 5 0})\end{array}$} \\
\cline { 2 - 4 } & $\mathbf{N o}$ & $\%$ \\
\hline- Poor & 4 & 2.7 \\
$-\quad$ Fair & 30 & 20.0 \\
- Good & 116 & 77.3 \\
\hline & & \multicolumn{2}{|c|}{$(50-114)$} \\
& Range & $85.33 \pm 11.583$ \\
\hline
\end{tabular}


Table (13): Correlation between levels of pediatric quality of life inventory of children and the levels of the parents according to their children using hearing device quality of life

\begin{tabular}{|c|c|c|c|c|c|c|c|}
\hline \multirow{4}{*}{$\begin{array}{l}\text { Levels of quality of life } \\
\text { inventory of the child }\end{array}$} & \multicolumn{6}{|c|}{$\begin{array}{l}\text { The studied school children } \\
\qquad(\mathrm{n}=150)\end{array}$} & \multirow{4}{*}{$\begin{array}{l}\chi^{2} \\
\mathbf{P}\end{array}$} \\
\hline & \multicolumn{6}{|c|}{$\begin{array}{l}\text { Scores of the studied parents according to their } \\
\text { children using hearing device quality of life. }\end{array}$} & \\
\hline & \multicolumn{2}{|c|}{$\begin{array}{c}\text { Poor } \\
(\mathbf{n}=28)\end{array}$} & \multicolumn{2}{|c|}{$\begin{array}{c}\text { Fair } \\
(\mathrm{n}=92)\end{array}$} & \multicolumn{2}{|c|}{$\begin{array}{c}\text { Good } \\
(\mathbf{n}=\mathbf{3 0})\end{array}$} & \\
\hline & No & $\%$ & No & $\%$ & No & $\%$ & \\
\hline - Poor & 2 & 1.3 & 2 & 1.3 & 0 & 0.0 & $120<2$ \\
\hline - Fair & 5 & 3.3 & 25 & 16.7 & 0 & 0.0 & \\
\hline Good & 21 & 14.0 & 65 & 43.3 & 30 & 20.0 & \\
\hline $\begin{array}{l}\mathbf{r} \\
\mathbf{P}\end{array}$ & & & $\begin{array}{r}0.4 \\
0.00\end{array}$ & & & & \\
\hline
\end{tabular}

* Significant at level $\mathrm{P}<0.05$.

** Highly significant at level $\mathrm{P}<0.01$ 


\section{Discussion}

Hearing impairment is one of the most common disabilities and has lifelong consequences for affected children and their families ${ }^{(26)}$. Hearing impairment in childhood is associated with difficulties in development of language, speech and cognition which in turn can compromise educational achievement, impair socialemotional function, lead to restricted employment opportunities that can directly affect the child quality of life ${ }^{(27,28)}$. Early detection together with appropriate intervention is critical to speech, language and cognitive development in hearingimpaired children ${ }^{(26)}$.

Parents of hearing impaired children usually feel swamped and unqualified managing their children in a beneficial manner. This anxiety in their own abilities is often exhibited as affliction. The level of parental involvement, quality, quantity and timing of care services that children receive is essential to their psychosocial, academic development and ultimately the quality of life they achieve. The parents of normal children have the responsibility to meet the needs of their children and prepare an appropriate environment for their children's healthy growth and development. The parent of a disabled child, however, in addition to these responsibilities, is also burdened with additional responsibilities ${ }^{(29)}$. Therefore, the aim of this study was to assess parents' perception level of quality of life of their elementary school children with hearing impairment using hearing aids.

Concerning the history of the academic educational achievement of the studied school children, the present study revealed that about half of the child's performance after fitting of hearing aids was fair. As regards to the effect of hearing device on the child attention in the class after fitting of the hearing device, the majority of them weren't affected and more than three quarters of them weren't faced any problem to communicate with classmates and teachers at school and the majority of them weren't absent from their school (Table I). This result may be due to that the children were adapted with hearing aids and they are interested with their academic education.

This finding goes in line with a study done by Schmucker et al., (2019) ${ }^{(30)}$, who observed that, the majority $(80.9 \%)$ of children were interested with academic education and adapted with their disease. This result is contradicted with Yeshoda et al., (2020) (31), who revealed that, the majority $(84.6 \%)$ of children didn't adapt with hearing loss.

Regarding the studied school children' parents perspectives and expectations, the findings of the present study showed that about more than one third of the studied 
school children's parents were reported that, sometimes their child easily have friends with other children, about half of their children spoken language was similar to typically developing children to their own age and about less than half of them believed that their children have greater educational opportunities and achievements with their hearing aids (Table 2). This result can be justified to that the studied school children try to initiate a relationship with other children to make friends rather than to be isolated with their hearing impairment. Furthermore, they are interested to play with them.

This result is in agreement with Marriage et al., (2017) ${ }^{(32)}$, who carried out a study to assess hearing impairment among children and mentioned that, more than half of children had friends and had good relationship with others. This current result is in contrary with Brännström et al., (2020) ${ }^{(33)}$, who conducted a study about perceived listening effort in children with hearing loss: listening to a dysphonic voice in quiet and in noise and reported that, three quarters of children were isolated due to their disease and had poor relations with others.

As regards to the studied school children's parents impact on their family, the results of the current study reveals that more than one third of the studied school children's parents reported that they rarely worry about whether the hearing device is working correctly. About half of them reported that sometimes their immediate family's activities are limited by their child's hearing needs and more than half had to change their working patterns since their child received the hearing device (Table 3). This may be contributed to the effect of hearing impairment on children's activities. In addition to that children were dependent on hearing aids in their life as well as this in turn have a negative effect on the family as a unit.

This result is in accordance with Muñoz et al., (2015) (34), who conducted a study about pediatric hearing aid use: Parentreported challenges and reported that, the parents changed their working times according to their children's treatment times. Furthermore, a study done by Olusanya et al., (2014) ${ }^{(35)}$, to investigate the global burden of disabling hearing impairment and stated that less than two thirds $(63.2 \%)$ of parents reported that, hearing impairment of children affected their family activities.

In relation to hearing-related quality of life of the studied school children, parents, the present study showed that more than one third of them reported that sometimes their child is able to communicate their needs using spoken language, about less than half of them were confident in social situations with typically developing children in the 
same age, about less than half of them speech is clear and can be understood by people who have not met them before, about less than half of them overhear conversation that is not directed at them and ask questions about what was said, more than two fifths of them keep up with their peers for daily learning activities at preschool/kindergarten/school and nearly one half of them often afraid of new situations (Table 4). This may be attributed to that the children's parents have a good communication skill with their children and they are able to adapt and accept the disease of their children in addition they are helping and encouraging them to participate in social situation.

This result is in the same line with a study done by Bisgaard and Ruf, (2017) ${ }^{(36)}$, about hearing loss prevalence, hearing aid adoption and benefits of hearing aid use and mentioned that, the majority $(82.5 \%)$ of children were participated in social situation and adapted with their disease. This result is in the opposite with the study carried out by Timmer et al., (2018) ${ }^{(37)}$, who reported that, the majority $(79.4 \%)$ of children were isolated in social situation and children speaks were unclear and didn't understood by others.

Regarding distribution of the studied school children's parents according to their domains levels of their children using hearing device (QoL). The current study illustrates that less than half of parent's perspectives and expectations of the studied school children's parents had fair and good score. Concerning the studied school children's parents according to their children using hearing devices impact on the family also about less than half had fair and poor score. Regarding the studied school children's parents according to their children using hearing device hearingrelated quality of life of the child about less than two thirds had a fair score (Table5).

This result may be due to that parent's perspectives and expectations about their children improved after fitting hearing aids compared to before fitting the device as a result of the effect of the device on the children life. As regards to the studied school children's parents according to their children using hearing devices impact on the family this result may be attributed to the additional needs of the hearing impaired children compared to normal hearing peers. This in turn slightly put additional stress on the hearing impaired children's families. Regarding the studied school children's parents according to their children using hearing device hearingrelated quality of life of the child, this result may be due to the studied children are adapted with their hearing device which has a positive impact on the child quality of life. 
This result in the same line with the study done by Ching et al., (2018) ${ }^{(38)}$, about factors influencing speech perception in noise for children using hearing aids or cochlear implants and reported that more than one half of the participants had moderate level of quality of life. Conversely, this result is contradicted with the study done by Lassaletta et al., (2012) (39) who studied quality of life in hearingimpaired children with bilateral hearing devices and found that less than two thirds of families were affected by the diseased children and act as burden on them.

Regarding the total score levels of the studied school children's parents using hearing aids quality of life, the current study revealed that about two thirds of them had a fair score and nearly one fifth had a good and a few of them had a poor score (Table 6). This result can be justified to that the parents were very interested with their children and they always help them to adapt with their life.

This result is in accordance with Kheri (2018) ${ }^{(40)}$, who carried out a study to assess the knowledge of children's parents with hearing impairment regarding care of hearing aids and found that, the majority $(88.3 \%)$ of children's parents had fair and good score of quality of life. Conversely, this result is contradicted with Uhlén et al., (2017) ${ }^{(41)}$, who stated that, the majority
$(80.4 \%)$ of children's parents had poor score of quality of life.

Concerning the studied school children health and activities problems, the present study demonstrated that nearly one half of them reported that they never had these problems (hard to walk more than one block, hard to do sports activities or exercises and hard to left something heavy respectively). In relation to the other child activities problems as they hurt or ache, it was reported that sometimes about less than two thirds of them had this problem (Table 7). This may be contributed to the effect of the disease on the physical activity of their children.

This result is congruent with a study done by Ukoumunne et al., (2017) ${ }^{(42)}$ who stated that, more than two thirds $(68.3 \%)$ of children hadn't physical difficulties or limitations of their activities. This finding is contradicted with a study done by Saravanan et al., (2019) ${ }^{(43)}$, who found that, three quarters $(75 \%)$ of children can't walk one hour a day. Also, this finding disagrees with Mehta et al., (2017) ${ }^{(44)}$, who studied the role of cortical auditory evoked potentials in reducing the age at hearing aid fitting in children with hearing loss identified by newborn hearing screening and mentioned that, the majority $(81.9 \%)$ of children can't play any sport or exercises. 
Regarding feelings problems of the studied school children, the present study revealed that, about two thirds of them showed that sometimes they feel sad or blue and more than half of them reported that sometimes they feel afraid or scared, feel angry and worry about what will happen to them respectively (Table 8). This might be due to the negative effect of the hearing impairment on the feeling of the children.

This finding was comparable with a study done by Alegre and Villar (2020) ${ }^{(45)}$, about exploring the emotional problems and mental health needs of elementary school children using cochlear implants or hearing aids in the Islas Canarias and stated that, the majority $(84.6 \%)$ of children had feeling of worry, and angry. Also, this finding in the line with the study done by Sofitć and Čošabić (2017) ${ }^{(46)}$, who showed that, the majority $(87.1 \%)$ of children were isolated and had feeling of angry.

With regards to the studied school children problems of getting along with others, the present study illustrated that less than one half of them reported that sometimes other children tease them, it is hard to keep up when they play with other children, have trouble for getting along with other children and other children do not want to be their friends respectively (Table 9). The possible explanation of this result is that, the children were isolated from other people. Moreover, the studied school children' parents were afraid on their children and also, from the negative effect of the hearing impairment on those children.

This finding is in congruence with a study performed by Rezaei et al., (2016) ${ }^{(47)}$, who found that, the majority $(87.5 \%)$ of parents were afraid on their children and they didn't able to keep their children safe. Also, this study in the contrary with another study done by Haghjoo et al., (2018) ${ }^{(48)}$, who observed that, about three quarters $(74.6 \%)$ of parents help their children to participate and play with other children to overcome isolation behaviors.

Concerning to the problems of the studied school children with their school, the present study represents that, about one half of them reported that sometimes find that it is hard to pay attention in class, while more than one third of them reported that, they often have trouble keeping up with their school work, they often miss school because they aren't feeling well and also they often miss school to go to the doctor or hospital respectively (Table 10). This may be due to the effect of hearing impairment on the level of concentration of the children because they are most of the times not available in their school and this will effect on their level of education.

This result is accordance with Appachi et al., (2017) ${ }^{(49)}$, who conducted a study to 
assess auditory outcomes with hearing rehabilitation among children with unilateral hearing loss and observed that, more than three quarters $(77.1 \%)$ of the children had low level of attention and difficult in understanding. Also, it is supported by another study carried out by Runnion (2017) ${ }^{(50)}$, who observed that, the majority $(83.6 \%)$ of children had difficult in understanding and hard attention.

Concerning the domains levels of pediatric quality of life inventory of studied school children, the present study illustrated that the majority of the studied school children had a good score of pediatric quality of life inventory health and activities, while more than half of them had a fair score of pediatric quality of life inventory according to child feelings. As regards to the studied school children problems of getting along with others, about less than one half of them had a fair score. Regarding the studied school children problems with school, three quarter of them had a good score, while less than fifth of them had a fair score. (Table 11).

This result may be attributed to that those children have no other physical disabilities or health problems and can do any activities as their normal hearing peers. As regards to child feelings, this result may be due to that the disease sometimes affects the hearing impaired children feelings. As regards to the studied school children problems of getting along with others, this result may be due to the effect of the hearing device on the studied children social development. Regarding the studied school children problems with school, this result may be attributed to that they are interested with their school.

In relation to the levels of pediatric quality of life inventory of the studied school children, the finding of the present study shows that more than three quarters of them had a good score related to the levels of pediatric quality of life inventory (Table 12). The possible explanation of this result might be justified to the children were adapted with their hearing impairment and using of hearing aids.

This result is in accordance with Nirmalasari et al., (2017) (51), who reported that, about more than half of the children had a good score related to the levels of pediatric quality of life. Conversely, this result is in contrary with a study performed by Lawal et al., (2016) ${ }^{(52)}$, who reported that, about less than three quarters $(72.3 \%)$ of the children had poor score related to the levels of pediatric quality of life.

The results of the current study present that, there was a highly statistically significant positive correlation between the levels of pediatric quality of life inventory of the studied school children and the 
levels of the studied school children's parents of their children using hearing devices quality of life as $(\mathrm{p}=0.000)$ and ( $\mathrm{r}=0.407)$ (Table 13).

This finding of the present study is in accordance with a study done by Cupples et al., (2018) ${ }^{(53)}$, who reported that, there was a highly significant positive correlation between the levels of pediatric quality of life inventory and their quality of life as perceived by their parents. This result is in the contrary with a study done by Wong et al., (2017) ${ }^{(54)}$, who stated that, there was a statistically significant negative correlation between levels of pediatric quality of life inventory of the studied school children and scores of the studied parents of their children using hearing devices quality of life.

\section{Conclusion}

Based on the findings of the present study, it can be concluded that less than two thirds of the studied school children' parents had a fair score according to their children using hearing devices quality of life, while nearly one fifth of them had a good and a poor score according to their children using hearing devices quality of life. More than three quarters of studied school children had a good score regarding to the levels of pediatric quality of life inventory, while about one fifth of them had a fair score and the minority of them had a poor score as regards to the levels of pediatric quality of life inventory.

\section{Recommendations}

Based on the results of the present study, it is recommended that:

1. Written instructions about hearing aids in the form of booklets or brochures should be provided to each child with hearing impairment using hearing aids and their parents in order to encourage them in effective adherence to the plan of care.

2. Regular screening for early signs of hearing impairment among school children especially children with family history of hearing impairment for early detection of children with hearing impairment as well as prevent its serious consequences.

3. Consistent training of parents on the support and communication skills with their hearing-impaired children.

4. School health nurse should develop health education programs to student's parents to enhance the parent's awareness regarding hearing impairment among children.

\section{References}

1. Islam M, Sattar A, Ali M. Prevalence and pattern of hearing loss. Medicine Today. 2011; 23(1): 18-21.

2. Guia A, Escarce A, Lemos S. Hearing health care network: The perspective of 
the user. Distúrb Comun. 2016; 28(1): 473-82.

3. Dimatos O, Ikino C, Philippi P, Dimatos S, Birck M, Freitas P. Profile of patients of the auditory health of the state of Santa Catarina served at HUUFSC. Int. Arquivos Internacionais de Otorrinolaringologia. 2011; 15(1): 59-66.

4. Duthey B. Background paper 6.21 hearing loss. Geneva: WHO Int, 2013.

5. Chadha S, Cieza A, Reyes K. Public health approach to hearing across the life course: A call-for-papers. Bulletin of the World Health Organization. 2018; 96(9): 592.

6. World Health Organization. Global costs of unaddressed hearing loss and cost-effectiveness of interventions: WHO report, Geneva. World Health Organization, 2017.

7. Brown C, Emmett S, Robler S. Global hearing loss prevention. Otolaryngologic Clinics of North America. 2018; 51(3): 575-592.

8. Adegbiji W, Olajide G, Olatoke F, Olajuyin A, Aremu S, Ali A, Eletta, P. Preschool children hearing impairment: Prevalence, diagnosis and management in a Developing Country. International Tinnitus Journal. 2018; 22(1): 1-6.

9. World Health Organization. Deafness and hearing loss: Fact sheet, 2018. Available at: https://www.who. int/news-room/fact- sheets/detail/deafness-and-hearingloss

10. Storbeck C. Childhood hearing loss in the developing world. International Journal of Child Health and Nutrition. 2012; 1(1): 59-65.

11. Hamid O, Shoukry T, Shehata W. Prevalence and pattern of hearing loss in children in house-held national survey in Egypt. Egyptian Journal of Ear, Nose, Throat and Allied Science. 2010; 11(2): 12-16.

12. Moodley S, Storbeck C. The role of the neonatal nurse in early hearing detection and intervention in South Africa: Pediatrics. Professional Nursing Today. 2012; 16(4): 28-31.

13. Oyewumi A, Adejumo O. An investigation of hearing loss among school age children through Audiological Assessment in Ibadan, Oyo State, Nigeria. Ilkogretim Online. 2011; 10(1):1-11.

14. Lammens F, Verhaert N, Devriendt K, Debruyne F, Desloovere C. Aetiology of congenital hearing loss: A cohort review of 569 subjects. International Journal of Pediatric Otorhino laryngology. 2013; 77(9):1385-1391.

15. Sarsfield L. Parenting a Child with Hearing Loss, 2014. Available at: https://dph.georgia.gov/sites/dph.georg ia.gov/files/MCH/unhsiRESOURCEgu ide2014.pdf 
16. Ogah S, Okomanyi A. Pattern of hearing loss as seen at the Federal Medical Centre Lokoja, Nigeria: A five year retrospective study. Asian J. Pharm Nurs. Med. Sci. 2014; 2(04): 87-89.

17. Raj P, Deeraj B, Ashwini M. Ayurvedic management of Bahira, conductive hearing loss-A case study. Pharma Science Monitor. 2017; $8(3): 17-25$.

18. Wilson B, Tucci D, Merson $M$, O’Donoghue G. Global hearing health care: New findings and perspectives. Lancet. 2017; 390(10111): 2503-2515.

19. Ohlenforst B, Zekveld A, Jansma E, Wang Y, Naylor G, Lorens A, et al. Effects of hearing impairment and hearing aid amplification on listening effort: A systematic review. Ear and Hearing. 2017; 38(3): 267-281.

20. World Health Organization .Childhood hearing loss: Strategies for prevention and care. 2016. Available at: https://apps.who.int/iris/bitstream/handle/1 0665/204632/9789241510325_eng.pdf

21. Perez-Mora R, Lassaletta L, Castro A, Herran B, San-Roman-Montero J, Valiente E, et al. Quality of life in hearing-impaired children with bilateral hearing devices. BENT. 2012; 8(4): 251-255.

22. Johansson B, Olsson L. Open access guide to audiology and hearing aids for otolaryngologists. Audiology for special populations: Infants. Creative Commons Attribution-Non

Commercial 3, 2013. Available at: https://open.umich.edu/sites/default/file s/downloads/audiologyforinfants.pdf

23. Looi V, Lee Z, Loo J. Hearing-related quality of life outcomes for Singaporean children using hearing aids or cochlear implants. European Annals of Otorhinolaryngology, Head and Neck Diseases, 2016; 80(1): 88-100.

24. Abdel-Fattah E. Factors impacting hearing aid performance outcomes for Egyptian hearing impaired children. Egyptian Journal of Ear, Nose, Throat and Allied Sciences, 2017; 18(1): 207-216.

25. Petersen S, Hägglöf $B$, Stenlund $H$, Bergström E. Psychometric properties of the Swedish PedsQL. Pediatric Quality of Life Inventory 4.0 generic core scales. Acta Paediatrica. 2009; 98(9):1504-1512.

26. Paludetti G, Conti G, Di Nardo W, De Corso E, Rolesi R, Picciotti P. Infant hearing loss: From diagnosis to therapy official report of XXI Conference of Italian Society of Pediatric Otorhinolaryngology. Acta Otorhinolaryngology Italica. 2012; 32(6): 347.

27. Ribeiro U, Souza V, Lemos S. Quality of life and social determinants in individual hearing AIDS users. In CoDAS. Sociedade 
Brasileira De Fonoaudiologia. 2019; 31(2): 1-9.

28. Jensen R, Koch A, Homøe P. The risk of hearing loss in a population with a high prevalence of chronic suppurative titis media. International Journal of Pediatric Otorhinolaryngology. 2013; 77(9): 1530-1535.

29. Zhang H, Nie R, Xiao A, Wang J, Du Y. Quality of life of HearingImpaired Middle School Students: A cross-sectional study in Hubei Province, China. Journal of Developmental and Physical Disabilities. 2020; 1(32): 826-827.

30. Schmucker C, Kapp P, Motschall E, Loehler J, Meerpohl J. Prevalence of hearing loss and use of hearing aids among children in Germany: A systematic review. BMC Public Health. 2019; 19(1): 1277.

31. Yeshoda K, Raveendran R, Konadath S. Perception of vocal emotional prosody in children with hearing impairment. International Journal of Pediatric Otorhinolaryngology. 2020; 12(6): 137.

32. Marriage J, Brown $\mathrm{T}$, Austin $\mathrm{N}$. Hearing impairment in children. Pediatrics and Child Health. 2017; 27(10): 441-446.

33. Brännström K, Lyberg-Åhlander V, Sahlén B. Perceived listening effort in children with hearing loss: Listening to a dysphonic voice in quiet and in noise. Logopedics Phoniatrics Vocology. 2020; 1-9.

34. Muñoz K, Olson W, Twohig M, Preston E, Blaiser K, White K. Pediatric hearing aid use: Parentreported challenges. Ear and Hearing. 2015; 36(2): 279-87.

35. Olusanya B, Neumann K, Saunders J. The global burden of disabling hearing impairment: A call to action. Bulletin of the World Health Organization. 2014; 92(5): 367-373.

36. Bisgaard N, Ruf S. Findings from EuroTrak surveys from 2009 to 2015: Hearing loss prevalence, hearing aid adoption, and benefits of hearing aid use. American Journal of Audiology. 2017; 26(3S): 451-461.

37. Timmer B, Hickson L, Launer S. Do hearing aids address real-world hearing difficulties for adults with mild hearing impairment? Results from a pilot study using ecological momentary assessment. Trends in Hearing. 2018; 22(1):1-15.

38. Ching T, Zhang V, Flynn C, Burns L, Button L, Hou S, et al.. Factors influencing speech perception in noise for children using hearing aids or cochlear implants. International Journal of Audiology. 2018; 57(1): S70-S80. 
39. Lassaletta L, Castro A, Herran B, SanRoman-Montero J, Valiente E, et al. Quality of life in hearing-impaired children with bilateral hearing devices. B-ENT. 2012; 8(4): 251-255.

40. Kheri M. Knowledge of Patients' With Hearing Impairment Regarding Care of Hearing Aids, Sudanese Hearing Center, Khartoum State, Sudan .PhD Thesis. University of Gezira. 2018. 187-192.

41. Uhlén I, Engström E, Kallioinen $P$, Nakeva C, Lyxell B, Sahlén B, et al. Using a multi-feature paradigm to measure mismatch responses to minimal sound contrasts in children with cochlear implants and hearing aids. Scandinavian Journal of Psychology. 2017; 58(5): 409-421.

42. Ukoumunne O, Hyde C, Ozolins M, Zhelev Z, Errington S, Taylor R, et al. A directly comparative two-gate casecontrol diagnostic accuracy study of the pure tone screen and hear check screener tests for identifying hearing impairment in school children. BMJ Open. 2017; 7(7): 261-274.

43. Saravanan G, Selvarajan H, McPherson B. Profiling classroom listening conditions in schools for children with hearing impairment. Noise and Health. 2019; 21(99): 83.
44. Mehta $K$, Watkin $P$, Baldwin $M$, Marriage J, Mahon M, Vickers D. Role of cortical auditory evoked potentials in reducing the age at hearing aid fitting in children with hearing loss identified by newborn hearing screening. Trends in Hearing. 2017; 21(1):1-16.

45. - Alegre O, Villar L. Exploring the emotional problems and mental health needs of elementary school children using cochlear implants or hearing aids in the Islas Canarias. Hearing, Balance and Communication. 2020; 18(3):1-9.

46. Sofitć F, Čošabić J. Implementation of Audiological Measurements at Persons with Hearing Impairment. In International Symposium on Innovative and Interdisciplinary Applications of Advanced Technologies Springer, Cham. 2017; 28: 751-758.

47. Rezaei M, Rashedi V, Morasae E. Reading skills in Persian deaf children with cochlear implants and hearing aids. International Journal of Pediatric Otorhinolaryngology. 2016; 89(1): 1-5. 48. Haghjoo A, Soleymani Z, Dadgar H. Effect of Cochlear Implant and Hearing aid on reading skill in Hearing-Impaired Children. Middle Eastern Journal of Disability Studies. 2018; 8: 69-69. 
49. Appachi S, Specht J, Raol N, Lieu J, Cohen M, Dedhia K, et al. Auditory outcomes with hearing rehabilitation in children with unilateral hearing loss: A systematic review. OtolaryngologyHead and Neck Surgery. 2017; 157(4): 565-571.

50. Runnion E. Variability of early literacy skills in children with hearing impairment, Doctorate thesis, Arizona State University. 2017. Available at: https://repository.asu.edu/attachments/ 186432/content/Runnion_asu_0010E_1 6906.pdf

51. Nirmalasari O, Mamo $S$, Nieman $C$, Simpson A, Zimmerman J, Nowrangi $\mathrm{M}$, et al. Age-related hearing loss in children with cognitive impairment. International Psychogeriatrics. 2017; 29(1): 115-121.

52. Lawal L, Karia M, Buttars C, Larsen J, Mulwafu W, Mukara K. Training teachers and parents on verbal communication among children with hearing impairment: Preliminary results from schools in Kenya. Journal of Communication Disorders, Deaf Studies and Hearing Aids. 2016; $4(2): 1-7$.

53. Cupples L, Ching T, Button L, Seeto M, Zhang V, Whitfield J, et al. Spoken language and everyday functioning in 10-year-old children using hearing aids or cochlear implants. International
Journal of Audiology. 2018; 57(1): S55-S69.

54. Wong C, Ching T, Leigh G, Cupples L, Button L, Marnane $\mathrm{V}$, et al. Psychosocial development of 5-yearold children with hearing loss: Risks and protective factors. International Journal of Audiology. 2017; 23(8): 81-92. 